\title{
Rural Problems during the Education Modernization Process in the Late Qing Dynasty and the Early Republic of China
}

\author{
Jing Xu \\ Party Propaganda Department, Ningxia University, Yinchuan 750021, China
}

\begin{abstract}
Keywords: the late Qing Dynasty and the early Republic of China, education, modernization, rural area
\end{abstract}

\begin{abstract}
The development of education modernization in the late Qing Dynasty and the early Republic of China is the beginning of education modernization process in China as well as an important component for its further development. Through a study of problems in rural education in early Republic of China, we can reveal the development law of rural education in China and find out its origin and relevance to current rural education policy in China. This paper summarized policies in education modernization in the late Qing Dynasty and the early Republic of China, introduced enlightenment of education in rural society in the late Qing Dynasty and the early Republic of China and expounded the evolvement of rural educational system reform in the late Qing Dynasty and the early Republic of China.
\end{abstract}

\section{Introduction}

This paper carried out an in-depth and systematic study on the development of rural education in the late Qing Dynasty and the early Republic of China to investigate the process of education reform in a more comprehensive way and analyze influences brought by education policies, summarize historical experiences and learn a lesson. Thus it is of great significance for the study of the development of rural education in China. Drawing a lesson from the history, we can not only know more detail about reform of rural education in the late Qing Dynasty and the early Republic of China in a scientific way but also enrich research on rural education policy in the late Qing Dynasty and the early Republic of China and it can also promote current rural education. Therefore, it has very profound and great value to be used for reference.

\section{Overview of Education Modernization Policies in the Late Qing Dynasty and the Early Republic of China}

In 1905, the imperial examination system was abolished, which symbolized the establishment of new educational system in China and indicated that education in China stepped into the process of modernization. As an important component of Chinese education, rural education experienced two major development processes in the education modernization policies since the establishment of interim government of Republic of China in 1912: namely, starting stage from 1912 to 1916 and progressing stage from 1917 to 1926. The political purpose of bourgeoisie, namely, striving to break the feudal regime gradually permeated and thus was directly reflected by rural education policies in early Republic of China. After Interim Measures for General Education and Interim Curriculum Standards for General Education were unveiled, the "Renzi·Kuichou Educational system" was issued and implemented. Later, local reforms in educational system were carried out at county level and city level with Compulsory Education Measures, Collected Educational Programs and National Education Plan prepared. After vernacular Chinese and mandarin Chinese were vigorously carried out, "Renxu Educational System" was put into practice as well as decisions concerning compulsory education policies, namely stipulations for plans to raise compulsory education fund. They were all modern rural education policies at that time. Although they repeatedly overturned reappearance of past education and involved in intense conflicts with the reappearance of past education and subjected to regime nature, it would always end with a result that the more advanced bourgeois educational policy would be accepted and popularized and further improved. At the same time, the scientificness and practicalness of rural education policy in the late Qing Dynasty and the early 
Republic of China also sought a process of localization of educational policy in continuous cyclic development.

\section{Enlightenment of Education in Rural Society in the Late Qing Dynasty and the Early Republic of China}

The first one is intellectuals' earnest practice to promote rural education. The initial establishment of new educational system mainly concentrated in urban areas thus urban education was severely separated from rural education. As a lot far-sighted educators and intellectuals gradually realized rural education fell behind, they didn't focus on large cities any more but instead, shifted their focus from urban areas to rural areas. And then rural education gradually developed in China. In early Republic of China, many ambitious and promising intellectuals gave up good living and working conditions in urban areas and went to rural areas to accomplish much. Through rural education, intellectuals carried out rural reforms including political and economic aspects with expectation to rescue China from crises arising from the Opium War fundamentally. Intellectuals tried to enlighten the public's wisdom with rural education and make the country regain vitality and energy. They exerted their utmost effort day and night and put forward many practical plans to reform rural education. In 1920's, celebrities in educational circles such as Yan Yangchu and Tao Xingzhi carried out rural education movement in Hebei, Jiangsu and Sichuan and vigorously advocated "saving the nation by education", thus making groundbreaking contributions to rural educational undertaking in China.

The second one is educators' personal involvement in rural education practice. Educators in early Republic of China combined their ideal with practical situation in rural area to carry out fruitful and proactive exploration. The educator, Tao Xingzhi put forward the view point of "rural education serves as the foundation underlying all our efforts to build the country". With all these educators' industrious efforts and selfless contributions, rural education achieved preliminary development and draw government's attention and concern at that time. The national government had to conform to the times and approve and support the education movement in rural areas so that the rural education movement in early Republic of China became a very important milestone, which even affected the development of education several decades later. Some far-sighted people in educational circles advocated education reformism and attempted to carry out reform to rural education so as to further improve rural life and actively pursue the ultimate goal of social harmony. Once the new life style fails to be put into practice and take root in rural areas, the country would be unable to achieve all-round development. Farmers in China have very low overall educational level and limited cultural quality, which is a great barrier that impacts the modernization process in rural areas and even nationwide. Therefore, the development of rural education should be taken seriously not only at that time but also in the contemporary time.

\section{Reform of Rural Educational System in the Late Qing Dynasty and the Early Republic of China}

\section{(I) Rural education policy system tended to be strengthened and perfected}

In the early Republic of China, to establish a modernized educational system which conformed to the development of bourgeois regime in order to break the backward rural educational mechanism in feudal society in the late Qing Dynasty became an important work of education authorities in early Republic of China. During this time, a large number of new educational decrees were issued to constantly enrich the content of education law. For example, the previous name of school, "Xuetang", was abandoned and free compulsory education was implemented in elementary schools. New curriculum standards were worked out to adjust "Renzi Educational System" and finally form "Renzi·Kuichou Educational System”. The bourgeois rural educational system was carried out in haste in the initial stage of the Republic of China. Later the resurgence of past education in feudal society occurred in 1915. Having experienced the thorough criticism of old culture in the New Culture Movement, the mainstream education concept in the educational circles 
in China completely tended to pursue the establishment and development of bourgeoisie education policy. Guided by such education policy, the rural education policy in China went deep into the most basic administrative division-rural areas so that educational administration became more convenient and flexible. As for the implementation of compulsory education, it's comprehensive and extensive, so that it could fully improve the populace's cultivation and cultivation of talents. As for the education goal, the Three People's Principles was emphasized in the early Republic of China so as to confirm the development tendency and development track of rural education. Under the basic framework of bourgeoisie education, the rural educational framework in early Republic of China was gradually strengthened and perfected. What's more, it played an increasingly important role in vigorously promoting the development of rural education.

\section{(II) Put the development of compulsory education in rural areas at the first place}

In the period of late Qing Dynasty and early Republic of China, great attention was paid to national education, especially the development of compulsory education in rural areas. Only when high attention is paid to rural education and vigorously promoting the development of compulsory education in rural areas can we earnestly complete the most basic and important content in educational development planning. In early Republic of China, rural areas occupied the most important component in national education in China. And this practical national condition thus determined that rural education would become the most important component of national education in China. The development condition of education in rural areas would eventually become an important basis for the development of rural education. We must put steadfast efforts to develop compulsory education in rural areas and regard it as priority among priorities in the development process of national education. It not only requires accurate understanding at theory level but also needs government to strong and substantial policy support to rural education in specific educational practice. The policy support and help from Government departments to the development of compulsory education in rural areas, relevant laws, regulations and policies were bound to become an important impetus to drive the scientific and stable development of compulsory education in rural areas in early Republic of China. And the guarantee of policies and systems served as the basis to guarantee all man power, material resources and financial resources needed when the compulsory education in rural areas was carried out. It can be seen from a series of policy documents focusing on compulsory education in rural areas issued by the national government and Ministry of Education such as Compulsory Education Measures issued in 1913 and Implementation Procedures of Compulsory Education issued in 1915 that in early Republic of China, great importance was attached to compulsory education in rural areas. It should be pointed out that unveiling direct or indirect policy documents concerning compulsory education in rural areas was of great significance in order to promote the development of compulsory education in rural areas and earnestly guarantee financial resources needed during the development of compulsory education in rural areas at that time so as to avoid any development trouble in construction of school building, teaching equipment layout, purchasing books and reference materials resulted from a lack of fund.

\section{(III) Strive to standardize education in rural areas in order to realize its scientific development}

The capitalistic rural educational system in early Republic of China is a brand new educational system and development pattern that was totally different from the traditional feudal education pattern throughout over 2000 years in ancient China. Because the traditional education concept existed for thousands of years and was deep-rooted, the development of modern education was thus under restrictions in many aspects, especially before the launch of the New Culture Movement which aimed to criticize old culture and old educational system, there were fierce and repeated conflicts between the democratic and advanced education idea and education practice and the feudal and backward education thought and education practice. And such conflicts ran through the whole development process of education policy in rural areas. The modernized development of rural education in the early Republic of China was really uneasy. However, education policy in rural areas still developed towards a scientific way gradually in this difficult process. Just because of such constant contradictions and conflicts, the modernization process of rural education was thus 
speeded up.

The scientization process of rural education policy in early Republic of China started when it's introduced quickly and then it was constantly enriched and improved through long-term conflicts with the reappearance of past education. Until the middle of Republic of China, it eventually gradually integrated into the development process of rural society in the Republic of China, especially after the establishment of Nanjing Republic Government, the national educational policy reform gradually developed in a scientific way towards the normalization of education policy. The government not only issued a multitude of laws and regulations successively to enhance educational administration and construction but also provided legal basis for matters that were yet to be settled after the new school education system was established; what's more, the government also worked out a lot of new systems to the benefit of constantly improving the quality of rural education, for example, textbook review system, teaching qualification system and discipline system, etc. Working out the above education systems and their standardized development laid a foundation for the modernization and scientization of rural education in China and put an end to the chaotic situation with conflicts between the new and old education systems in late Qing Dynasty and early Republic of China, so that it would help stabilize the education order in rural areas and the improvement of teaching quality. Carrying out the above education policies including education policy in rural areas was also a useful method for the Republic Government to strengthen education control and maintain its dominance. However, the legislation and scientization in working out and developing the series of educational policies in rural areas in early Republic of China also played an active role in the development of rural education throughout the whole period of Republic of China.

\section{Conclusion}

In early Republic of China, it seemed urgent to work out a new rural educational system that would meet the Republic Government's requirements to completely abandon the backward educational system in late Qing Dynasty. Under such situation, the Chinese bourgeoisie unveiled the first educational system, namely "Renzi-Kuichou Educational System" as the times required. This educational system imitated Japanese educational system and adopted Japanese educational pattern which copied the educational pattern in Germany and France, thus it broke away from the practical national conditions in early Republic of China. The educational system lacked flexibility and appeared too uniform, thus limited flexible methods to run schools according to practical conditions in different places. Because of problems and deficiencies in this educational system itself, different places required to reformulate appropriate educational systems. Through long-term extensive theoretical research and practice conclusion, the new educational system, namely "Renxu Educational System" came into being in 1922. Although this educational system still imitated that in America, it conformed to the practical situations in China because it took a long time to prepare and research. Through constant reform and improvement, the new learning education with a new appearance in late Qing Dynasty and early Republic of China eventually stepped on a scientific and standardized path to modernization and promoted the modernization process in rural society and even the modernization process of Chinese society.

\section{Acknowledgments}

This paper is funded by 2013 Ningxia University Scientific Research Fund. Project Name: Reform of Educational System and Changes in Rural Society in Modern China-Rural Problems during the Education Modernization Process in the Late Qing Dynasty and the Early Republic of China, Fund No.: SK1358

\section{References}

[1] Xiong Xianjun. A Great Cause-Study on Compulsory Education in Modern China [M]. Wuhan: Central China Normal University Press, 1998 
[2] Huang Shuguang. Historical Reflection and Prospects of China's Basic Education Reform [M]. Tianjin: Tianjin Education Press, 2006

[3] You Haihua. Rural Modernization in an Educator's View-a Survey to Linqiao Experimental Plot in Yichun in the Republic of China [J] Journal of Yichun University, 2013 (4)

[4] Wang Cheng. Rural Education in the Period of the Republic of China and Repevent Problem of Funds [J] Journal of Chang'an University (Social Science Edition), 2013 (1)

[5] Cheng Bicheng. "Rural Educational Movement” in Republic of China and its Inspiration for Rural Education Reform [J] Journal of Teaching and Management, 2014 (6) 